\title{
Pengelolaan Air Asam Tambang dari Batuan Sisa di Pit Barani dan Ramba Joring serta Aplikasi Model Enkapsulasi pada Bendungan Tailing di Tambang Emas Martabe
}

\author{
Latipa Henim Siregar $^{1^{*}}$, Zulkifli Nasution ${ }^{2}$ Fatimah $^{3}$ \\ ${ }^{1}$ Sekolah Pascasarjana, Pengelolaan Sumber Daya Alam dan Lingkungan, Universitas Sumatera Utara, Medan. \\ ${ }^{2}$ Program Studi Agroteknologi, Fakultas Pertanian, Universitas Sumatera Utara, Medan. \\ ${ }^{3}$ Program Studi Teknik Kimia, Fakultas Teknik, Universitas Sumatera Utara, Medan. \\ *Koresponden email: latipahenims@gmail.com
}

Diterima: 17 Mei 2021

Disetujui: 31 Mei 2021

\begin{abstract}
Acid mine drainage is one of the significant negative impacts of mining activities that can result in environmental degradation. Waste rock is mine waste that is found in large quantities and can produce acid mine drainage (AMD). This study aims to identify waste rock which has the potential to generate acidity (PAF) and do not generate acidity (NAF) in the Barani and Ramba Joring pits and the application of the encapsulation model in tailings dams. The research method with the encapsulation model is a simple method designed in tailings dams to encapsulate the PAF with the NAF. Rock characterization and geochemical analysis will result in the rock being classified as PAF and NAF in both wells. The data used for this study are drilling data (cutting) data that include rock lithology and chemical quality (NAPP and NAG) data. The results identified that the PAF was dominant relative to the NAF both wells and the waste rock in the Barani pit was at a higher risk of producing acidity than the Ramba Joring pit. Measurements of oxygen diffusion and surface water quality indicated that encapsulation of waste rock in the tailings dam may prevent the formation of acidic mine drainage.
\end{abstract}

Keywords: acid mine drainage, waste rock, mine waste, PAF, NAF

\begin{abstract}
Abstrak
Air asam tambang adalah merupakan salah satu dampak negatif signifikan dari aktivitas penambangan, yang dapat menimbulkan degradasi lingkungan. Batuan sisa adalah merupakan limbah tambang yang ditemukan dalam jumlah yang besar, yang berpotensi menimbulkan air asam tambang (AAT). Penelitian ini bertujuan untuk mengidentifikasi batuan sisa yang berpotensi membentuk keasaman (PAF) dan yang tidak berpotensi membentuk keasaman (NAF) di pit Barani dan Ramba Joring, serta penerapan enkapsulasi model pada bendungan tailing. Metode penelitian dengan enkapsulasi model merupakan metode sederhana yang dirancang di bendungan tailing yang bertujuan untuk membungkus batuan sisa PAF dengan batuan penyegel NAF. Karakterisasi batuan dan analisa geokimia akan menghasilkan klasifikasi batuan sisa ke dalam PAF dan NAF di pit Barani dan Ramba Joring. Data yang digunakan pada penelitian ini berupa data pemboran (cutting) yaitu data litologi dan kualitas kimia batuan (NAPP dan NAG). Hasil penelitian mengindikasikan kalau batuan sisa PAF lebih dominan daripada NAF pada kedua pit dan batuan sisa di pit Barani lebih beresiko menghasilkan keasaman daripada pit Ramba Joring. Pengukuran difusi oksigen dan kualitas air permukaan menunjukkan kalau enkapsulasi batuan sisa pada bendungan tailing dapat mencegah terbentuknya air asam tambang.
\end{abstract}

Kata Kunci: Air Asam Tambang, Batuan Sisa, Limbah Tambang, PAF, NAF

\section{Pendahuluan}

Tidak bisa dipungkiri kalau industri pertambangan yang disebabkan oleh sifat kegiatannya, dapat menimbulkan dampak, baik dari sisi lingkungan maupun sisi sosial. Air Asam Tambang (AAT) adalah merupakan salah satu dampak dari industri pertambangan, yang harus ditangani secara serius karena dapat menimbulkan degradasi kualitas lingkungan. Salah satu faktor terjadinya air asam tambang adalah kehadiran mineral sulfida pada batuan. Seiring dengan aktivitas penambangan, seperti penggalian dan penimbunan yang menyebabkan batuan sisa yang mengandung mineral sulfida terpapar ke udara dan air sehingga menghasilkan air asam tambang [1]. Terbentuknya air asam tambang ditandai oleh $\mathrm{pH}$ yang rendah (1.5 - 3), konsentrasi logam terlarut tinggi (besi, aluminium, mangan, cadmium, tembaga, timbal, seng, arsenik dan merkuri), acidity atau keasaman yang tinggi, nilai sulfat yang tinggi serta konsentrasi oksigen terlarut yang rendah [2]. 
Batuan sisa adalah batuan yang tidak mengandung mineral berharga yang melingkupi batuan yang mengandung mineral atau tubuh bijih yang harus disingkirkan atau dibuka untuk penambangan bijih, yang berpotensi menghasilkan air asam tambang yang terbentuk dari paparan mineral sulfida saat penggalian[3]. Tambang emas Martabe yang dioperasikan oleh PT. Agincourt Resources telah mengembangkan manajemen pengelolaan air asam tambang (AAT), untuk mengidentifikasi batuan sisa yang berpotensi membentuk asam (PAF) dan batuan sisa yang tidak berpotensi menghasilkan asam (NAF), dengan mengembangkan basis data karakteristik geologi dan uji geokimia asam basa (ABA/Acid Base Accounting) untuk mendapatkan nilai NAPP dan NAG.

Metode NAPP (Net Acid Production Potential/ Potensi Produksi Asam Netto) adalah merupakan metode pencegahan pembentukan air asam tambang melalui identifikasi karateristik batuan dengan menggunakan potensi keasaman maksimum (MPA/Maximum Potential Acidity) yang diturunkan dari \% berat sulfida, dan kapasitas netralisasi asam (ANC/Acid Neutralization Capacity) wt\% Ca [4]. NAG (Net Acid Generation) merupakan analisa jumlah potensi keasaman yang terbentuk setelah terjadi reaksi pirit dalam batuan di area tambang. Adapun reaksi yang terjadi dalam NAG antara lain, reaksi keasaman dan penetralan dengan hasil akhir reaksi oksidasi adalah nilai NAG pH yang menunjukkan indikasi sifat keasaman atau kebasaan dari sampel batuan [5].

Bendungan tailing (TSF/Tailing Storage Facility) adalah bendungan yang dibangun secara bertahap dan dioperasikan saat masih dalam tahapan konstruksi dan merupakan tempat penyimpanan tailing hasil sisa pemisahan emas - perak dari pabrik dalam bentuk lumpur (slurry) dan sekaligus tempat penyimpanan batuan sisa [6]. Batuan sisa tambang dari seluruh pit di Martabe akan ditempatkan di sebelah selatan dari tanggul TSF yang dikembangkan sebagai struktur utama penahan hilir yang disebut dengan Waste Rock Storage Facility (WSRF), dengan metode enkapsulasi sederhana. WRSF ini akan mencakup semua batuan sisa, termasuk batuan sisa pembentuk asam (PAF) yang di gali dari semua deposit yang saat ini sedang di tambang [7].

Tambang Emas Martabe mengembangkan protokol operasional pengelolaan batuan sisa sebagai bagian dari pengelolaan Air Asam Tambang (AAT) yang bertujuan untuk mencegah terjadinya aliran air asam tambang. Curah hujan yang cukup tinggi di lokasi penambangan merupakan salah satu faktor yang bisa memicu terpaparnya mineral sulfida yang ada pada batuan sisa [8]. Metode enkapsulasi atau sealing layer diharapkan dapat memberikan benefit ganda bagi perusahaan sekaligus untuk lingkungan, karena selain bertujuan untuk mencegah terjadinya air asam tambang, batuan sisa tersebut juga dimamfaatkan untuk konstruksi peninggian bendungan tailing di tambang emas Martabe [9]. Penempatan batuan sisa di bendungan tailing dilakukan dengan desain teknik yang bersertifikasi. Pemantauan rutin terhadap metode enkapsulasi ini dilakukan dengan pengecekan kualitas air permukaan dan oxygen ingress pada bendungan tailing.

\section{Metode Penelitian}

Penelitian ini merupakan penelitian dengan metode eksperimental, dengan melakukan pengambilan data di lapangan (field experiment) dan pengujian di laboratorium (laboratory experiment). Penelitian ini memanfaatkan data pemboran grade control yang berbentuk cutting yang dianalisa dengan metode ABA (acid base accounting), ASD dan XRD, pengukuran $\mathrm{pH}$ air permukaan pada bendungan tailing serta data curah hujan selama tahun 2020 sebagai data sekunder. Metode yang diterapkan dalam pengambilan data kualitas kimia batuan yaitu menggunakan uji statik dengan menggunakan Net Acid Producing Potential (NAPP) untuk pit Barani dan Net Acid Generation (NAG) untuk pit Ramba Joring.

\section{Lokasi Penelitian}

Penelitian dilakukan di tambang emas Martabe, pada dua lokasi pit yang berbeda, yaitu pit Barani pada elevasi 330 dan Ramba Joring di elevasi 630. Tambang emas Martabe terletak di Kecamatan Batangtoru, Kabupaten Tapanuli Selatan, Provinsi Sumatera Utara. Lokasi penelitian dapat dilihat pada Gambar 1. 


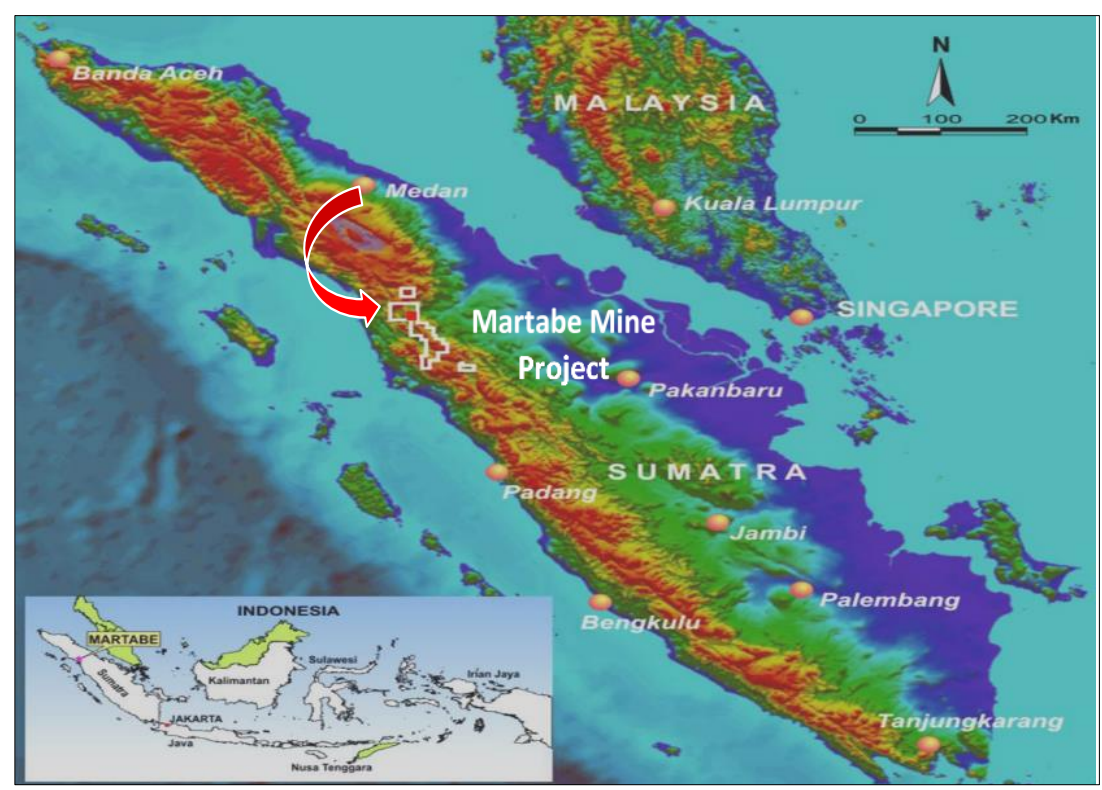

Gambar 1. Lokasi penelitian

Sumber: Martabe Kontak Karya, PTAR 2014

\section{Alat dan Bahan}

Alat yang digunakan untuk pengambilan data dalam penelitian ini adalah seperangkat mesin pemboran RC (Reverse Circilation), splitter sampel, kantong sampel dan alat tulis. Bahan yang dibutuhkan dalam penelitian ini adalah peta geologi pit Barani dan Ramba Joring, data curah hujan dan data pengukuran difusi oksigen pada bendungan tailing selama tahun 2020, yang didapatkan dari PT. Agincourt Resources. Alur Penelitian

Penelitian ini dilakukan dengan mengikuti bagan alir seperti terlampir pada Gambar 2.

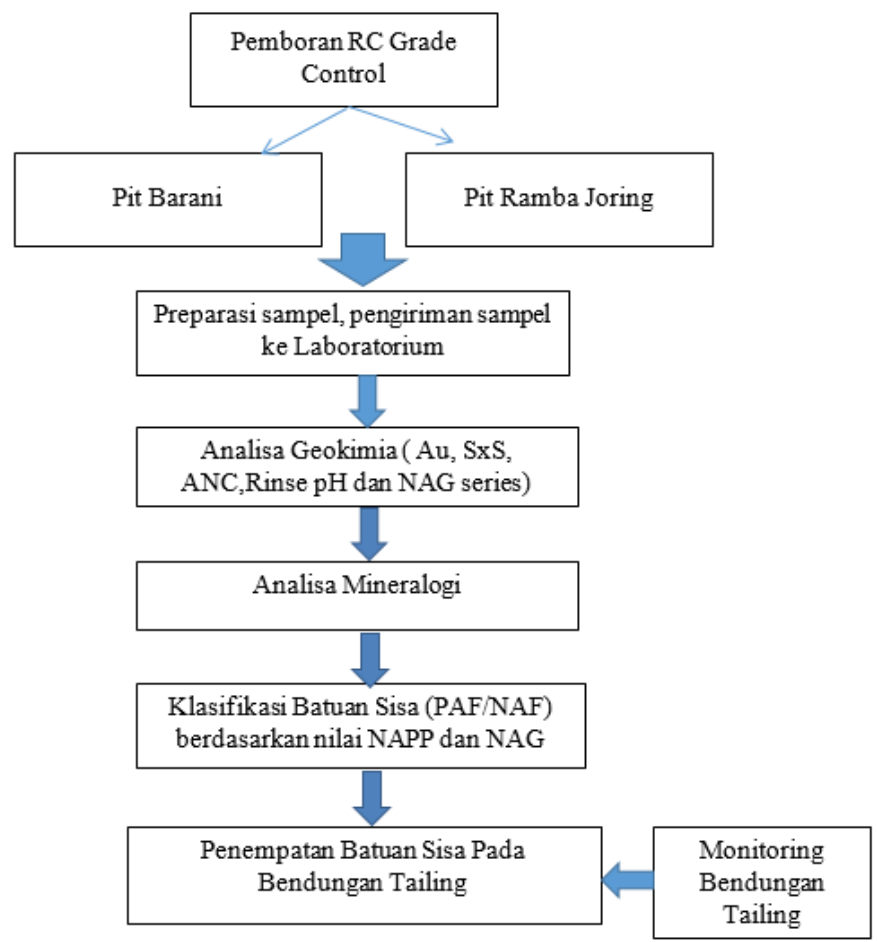

Gambar 2. Bagan alir proses penelitian Sumber: Analisa batuan sisa PTAR 2020 


\section{Deskripsi Batuan Sisa}

Sampel yang digunakan dalam analisis kimia batuan sisa berasal dari pemboran cutting di pit Barani sebanyak 59 titik dan Ramba Joring 21 titik. Pengambilan data dimulai dari pendeskripsian litologi dan alterasi untuk semua sampel batuan. Setelah pendeskripsian batuan, kemudian dilakukan preparasi sampel dan pengiriman ke laboratorium untuk uji kimia NAPP (pit Barani) dan NAG (Ramba Joring). Sampel diambil tiap kedalaman satu meter dengan total kedalaman masing-masing titik sama dengan 12 meter, dan berat rata-rata $2-3 \mathrm{~kg}$. Jarak antar satu titik pemboran dengan yang lain bervariasi, sekitar $6,5 \times 12,5 \mathrm{~m}$ sampai 12,5 x 25 meter mewakili semua jenis batuan dan alterasi yang ada pada pit Barani dan Ramba Joring.

\section{Analisa Mineralogi (XRD dan ASD)}

Analisa mineralogi pada batuan sisa bertujuan untuk mengidentifikasi asosiasi mineral yang terdapat pada batuan termasuk spesies sulfida sebagai penghasil asam dan juga spesies penetral yang terkandung dalam batuan sisa. Analisa mineralogi yang dilakukan dalam penelitian ini ada dua, yaitu dengan metode XRD (X-ray Diffraction) dan metode ASD (Analytical Spectral Divices).

XRD dilakukan dengan membuat 3 sampel bubuk (pulp) dari masing-masing pit, kemudian dikirimkan ke laboratorium Geoservice Jakarta untuk dianalisa. Metode XRD digunakan untuk menentukan jenis struktur, ukuran butir dan konstanta kisi, dimana hasil perekamannya berupa intensitas difraksi sinar$\mathrm{X}$. Hasil analisa XRD dapat menentukan mineral alterasi hidrotermal yang tidak diketahui baik secara megaskopis maupun mikroskopis [10].

Analisa ASD dilakukan dengan mengambil sampel cutting dari 5 titik pemboran di Barani dan 4 di Ramba Joring, dengan menggunakan alat ASD portable jenis ASD Terraspec3. ASD merupakan spektrometer portable yang dapat mengidentifikasi mineral dengan mengukur absorpsi spektral vibrasionalnya. Gambaran absorpsi ini diakibatkan oleh variasi komposisi, kristalinitas dan orientasi mineral. Alat ASD ini akan merekam data yang ada pada sampel, dengan cara menembakkan alat ASD tersebut pada sampel batuan dan akan dideteksi oleh komputer atau laptop dan menghasilkan kurva panjang gelombang. Variasi panjang gelombang ini yang akan menentukan kumpulan mineral alterasi hidrothermal, khususnya mineral clay (lempung) [11].

\section{Analisa Kimia dengan Uji NAPP}

Net Acid Production Potential merupakan metode yang paling umum digunakan untuk identifikasi karateristik batuan sisa dengan menggunakan nilai Potensi Keasaman Maksimum (MPA) yang diturunkan dari \%sulfida dan Kapasitas Netralisasi Asam (ANC), biasanya diwakili oleh mineral Ca. Pit Barani menggunakan uji NAPP untuk klasifikasi batuan sisa di ke dalam PAF dan NAF. NAPP negatif menunjukkan kalau sampel memiliki kapasitas netralisasi bersih dan NAPP positif menunjukkan kalau memiliki kapasitas penghasil asam bersih. Klasifikasi batuan sisa di pit Barani dengan menggunakan nilai NAPP dapat dilihat pada Tabel 1 [12].

Tabel 1. Klasifikasi batuan sisa di Pit Barani berdasarkan nilai NAPP

\begin{tabular}{lcl}
\hline Kelompok & NAPP & Jenis Batuan \\
Batuan Sisa & $<0$ & Lith $\neq \mathrm{BFZ}$, SxS $<0,5$ \\
\hline NAF & $0-5$ & Lith $\neq \mathrm{BFZ}$ \\
PAF-Low Risk & $>5<20$ & Lith $\neq \mathrm{BFZ}$ \\
PAF-3A & $>20-90$ & Lith $\neq \mathrm{BFZ}$ \\
PAF-3 & $>90$ & Lith $=\mathrm{BFZ}$ \\
PAF-High Risk & $>5-90$ & Lith $\neq \mathrm{BFZ}, \mathrm{Ca}>0,4 \%$ \\
PAF-Lag & - Perubahan untuk cut off Agustus 2019 (PTAR)
\end{tabular}

\section{Analisa Kimia dengan Uji NAG}

NAG (Net Acid Generation) merupakan analisa jumlah potensi keasaman yang terbentuk setelah terjadi reaksi pirit dalam batuan di area tambang. Pit Ramba Joring menggunakan analisis NAG pH untuk pembagian batuan sisa ke dalam PAF dan NAF, karena dianggap merupakan metode uji yang paling cocok untuk mengidentifikasi mineral sulfida yang terdapat pada batuan pit Ramba Joring yang kaya akan alunite. Alunite adalah merupakan mineral sulfat non generate acid, yang berfungsi sebagai buffer untuk oksidasi mineral pirit dalam batuan. Klasifikasi batuan sisa di pit Ramba Joring berdasarkan nilai NAG pH4.5 disajikan pada Tabel 2 [13]. 
Tabel 2. Klasifikasi batuan sisa di Pit Ramba Joring berdasarkan nilai NAG pH 4,5

\begin{tabular}{lcl}
\hline $\begin{array}{l}\text { Kelompok } \\
\text { Batuan Sisa }\end{array}$ & NAG pH 4.5 & Jenis Batuan \\
\hline NAF & $<0.01$ & Lith $\neq$ BFZ, SxS $<0,5$ \\
PAF-Low Risk & $<5$ & Lith $\neq$ BFZ \\
PAF (medium) & $20-80$ & Lith $\neq$ BFZ \\
PAF-High Risk & $>80$ & Lith $=$ BFZ \\
PAF-Lag & ANC $>10$ & Lith $\neq$ BFZ \\
\hline
\end{tabular}

Sumber: Memo Steven 08 Agustus 2019 - Perubahan untuk cutt off Agustus 2019 (PTAR)

\section{Klasifikasi Batuan Sisa}

Nilai NAPP dan NAG pH 4.5 pada setiap sampel batuan yang dihasilkan dari uji laboratorium digunakan sebagai dasar pengelompokan batuan sisa ke dalam PAF dan NAF (terlampir pada tabel1 dan 2). PT Agincourt Resources tidak hanya membagi batuan sisa ke dalam PAF dan NAF, tetapi dibagi lagi ke dalam PAF-Low Risk, PAF-medium (PAF-3A dan PAF-3), PAF-High Risk dan PAF-Lag. Selain data NAPP, terdapat data pendukung lainnya seperti data XRD, ASD dan data litologi. Pemilihan uji kimia batuan sisa didasarkan pada perbedaan komposisi serta sifat mineral pada masing-masing pit.

\section{Hasil dan Pembahasan}

Berdasarkan hasil analisa geokimia batuan sisa dengan metode NAPP di pit Barani, ditemukan kalau sebagian besar sampel merupakan kategori PAF-Low Risk dan PAF-3 (medium). Hasil analisa 523 sampel ditemukan 44 sampel kategori NAF, 218 PAF-Low Risk, 108 PAF-3A, 122 PAF-3, 21 PAF-High Risk dan 10 PAF-Lag. Pembentukan PAF dan NAF dipengaruhi oleh jenis batuan dan alterasinya. Batuan yang memiliki ukuran butir dan susunan butir seragam akan memiliki permeabilitas yang besar untuk meloloskan fluida, sedangkan batuan sisa dengan butiran menyudut atau beragam akan memiliki permeabilitas yang kecil. Permeabilitas akan menentukan banyaknya fluida yang termineralisasi yang dapat masuk ke dalam batuan. Semakin besar permeabilitasnya maka akan semakin berpotensi untuk membentuk batuan PAF. Alterasi pada batuan mengindikasikan temperatur dan keasaman, batuan PAF akan cenderung terbentuk pada alterasi AA dan SI, sedangkan batuan NAF mendominasi alterasi argillik.

Berdasarkan hasil deskripsi batuan sisa di pit Barani ditemukan 6 jenis batuan, yaitu hidrothermal breccia (BHX), breccia phreatomagmatic (BPM), quartz vein (QTZ), conglomerate (SCG), siltstone (SSL), sandstone (SST), dan volcanic breccia (VBX). Batuan sisa PAF didominasi oleh Siltstone dan sandstone, merupakan batuan dengan susunan butir seragam (permeabilitas tinggi), sedangkan batuan sisa NAF disominasi oleh VBX, BPM dan SCG yang merupakan batuan dengan susunan butir menyudut dan beragam (permeabilitas kecil). Klasifikasi batuan sisa di pit barani berdasarkan nilai NAPP dan penyebaran litologi, dapat dilihat pada Gambar 3.

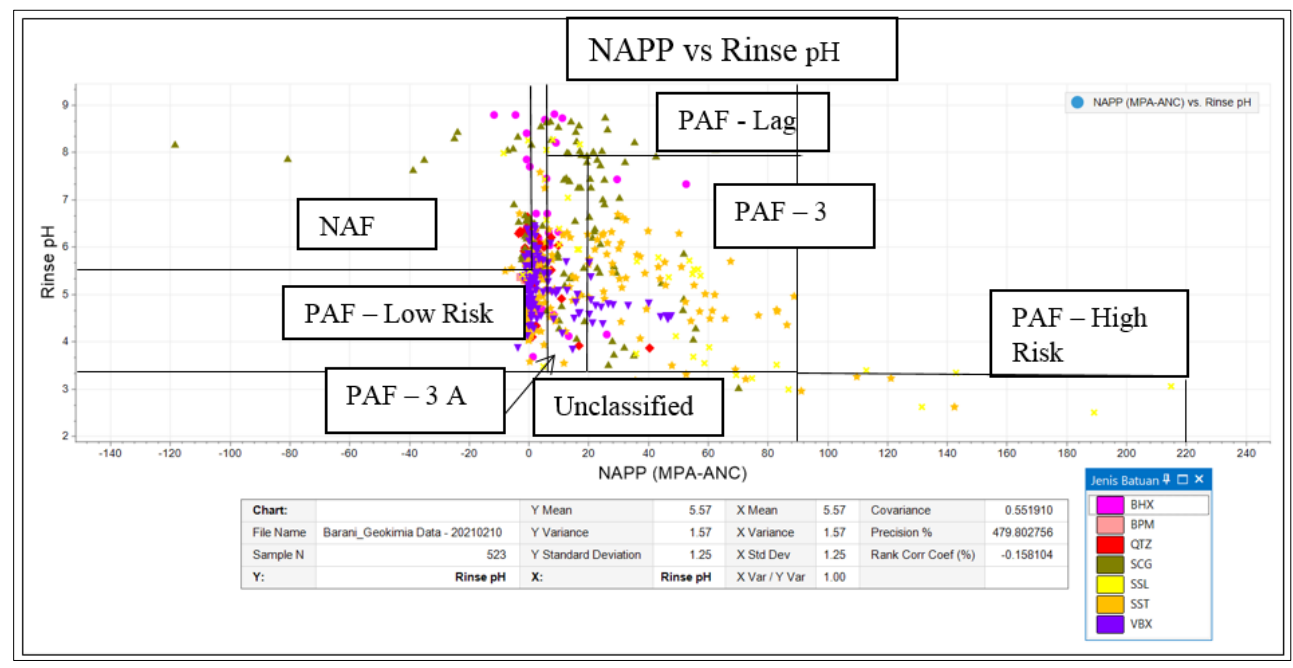

Gambar 3. Klasifikasi batuan sisa berdasarkan nilai NAPP Sumber: Pengolahan data geokimia batuan sisa di Pit Barani, 2020 
Secara fisik batuan NAF dan PAF dapat dibedakan dari warna, dimana NAF memiliki warna lebih terang seperti abu-abu muda dan kemerahan, sedangkan PAF memiliki warna abu-abu gelap dan hitam, seperti terlihat pada Gambar 4.
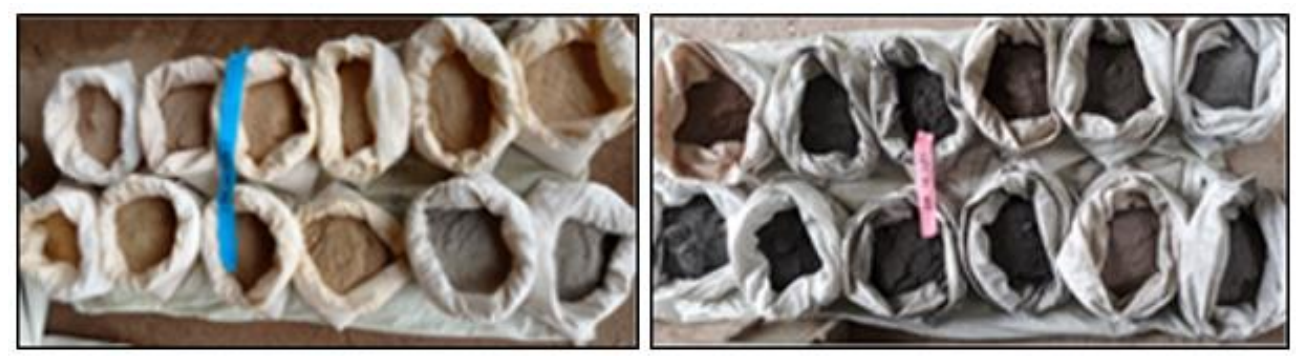

Gambar 4. Batuan sisa NAF (Kiri) dan PAF-high risk kanan di Pit Barani Sumber: Data lapangan, 2020

Selain uji geokimia dan deskripsi batuan, juga dilakukan analisa mineralogi (ASD dan XRD) untuk melihat komposisi mineral pada batuan, yang berpotensi membentuk keasaman dan yang bersifat sebagai penetral (buffer). Hasil analisa ASD dan XRD di pit Barani, ditemukan mineral oksidasi hematite-geothite dan jarosite (?) sebagai hasil oksidasi mineral pirit pada $\mathrm{pH}$ rendah, yang berpotensi menghasilkan keasaman dan ditemukan juga mineral calcite sebagai mineral penetral asam dalam jumlah yang sangat terbatas.

Klasifikasi batuan sisa di Pit Ramba Joring tidak menggunakan metode NAPP, tetapi menggunakan NAG pH 4,5. Perbedaan metode geokimia pada ke dua pit ini didasarkan pada perbedaan komposisi mineralnya. Berdasarkan hasil analisa XRD dan ASD, Pit Ramba Joring didominasi oleh mineral alunite (K Al3 (S O4)2 (O H)6), yang bertindak sebagai penahan produksi keasaman (oksidasi pirit), karena efek pelarutan alumunium. Kehadiran mineral sulfat alunite tersebut akan mengganggu analisa sulfur sulfida (metode SCIS), yang hanya akan larut sebagian dalam natrium karbonat sebagai elektron umum yang digunakan dalam metode SCIS. Pengujian NAG dianggap lebih sesuai untuk mendeteksi keasaman pada batuan yang mengandung alunite, karena sampel direaksikan dengan oksidator kuat sehingga mempercepat proses oksidasi berbagai kandungan mineral sulfida yang terdapat pada batuan.

Berdasarkan hasil analisa NAG pH 4.5 dari 218 sampel di pit Ramba Joring, ditemukan 26 sampel kategori NAF, 170 PAF-Low Risk, 2 PAF-medium dan 20 PAF-High Risk. Komposisi batuan sisa di pit Ramba Joring lebih simpel dibandingkan dengan pit Barani, hanya terdiri dari 2 jenis batuan yaitu volcanic andesite hornblende (VANH) dan breccia phreatomagmatic (BPM). Batuan NAF didominasi oleh batuan VANH dan batuan PAF menempati semua jenis batuan (BPM dan VANH). Klasifikasi batuan sisa di pit Ramba Joring berdasarkan nilai NAG pH 4.5 dan penyebaran litologi, dapat dilihat pada Gambar 5.

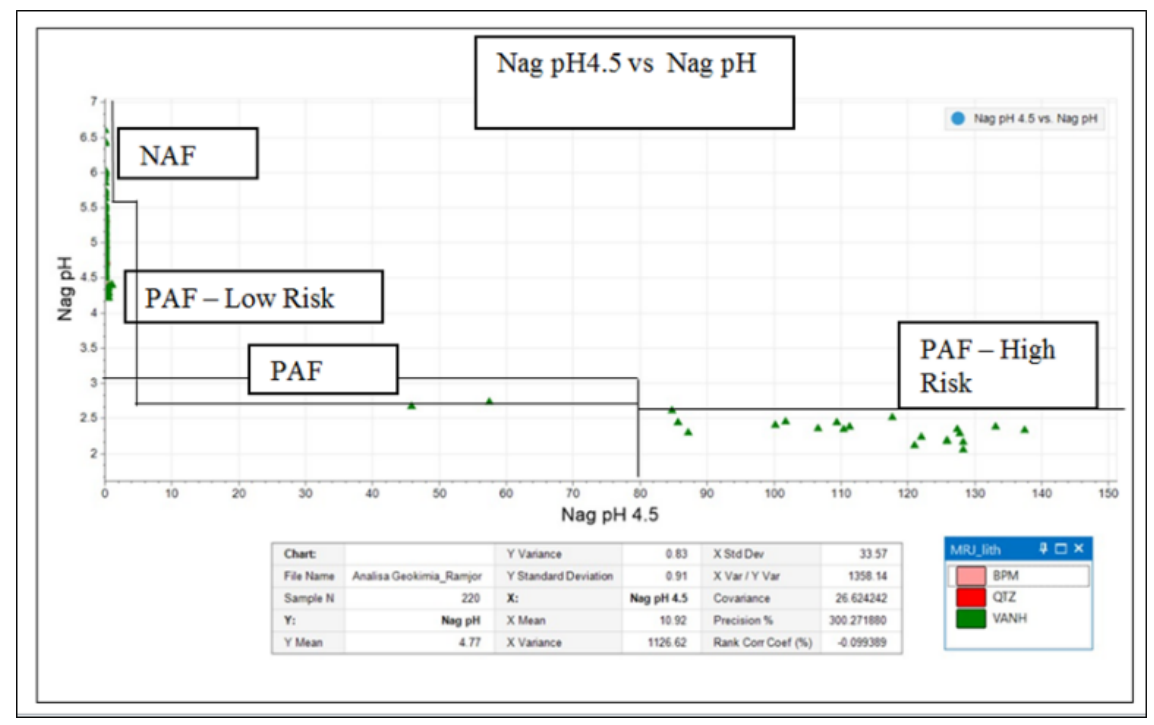

Gambar 5. Klasifikasi batuan sisa berdasarkan nilai NAG pH 4.5

Sumber: Pengolahan data geokimia batuan sisa di Pit Ramba Joring, 2020 
Batuan sisa PAF dan NAF dari pit Barani dan Ramba Joring akan ditempatkan di bendungan tailing dengan metode enkapsulasi (sealing layer). Berdasarkan hasil pengujian geokimia dan spesifikasi geologi, ditemukan 3 kelas atau kategori yang bisa digunakan sebagai lapisan penyegelan, yaitu kelas 1 (NAF), kelas 2 (PAF-Low Risk), dan kelas 5 (PAF-Lag). NAF merupakan batuan utama yang digunakan sebagai bahan penyegel yang bertujuan untuk menghambat masuknya oksigen, kecuali yang berukuran kasar lebih cocok untuk konstruksi. Batuan sisa NAF merupakan bahan yang beresiko paling rendah dan diharapkan tidak menghasilkan air asam tambang. PAF-Low Risk termasuk kategori batuan sisa yang dapat menghasilkan keasaman dalam tingkat yang paling rendah dan dapat digunakan sebagai bagian penyegel apabila NAF tidak tersedia. PAF-Lag merupakan batuan sisa yang berpotensi menghasilkan keasaman, tetapi memiliki kapasitas penyangga yang cukup dengan hadirnya mineral calcite, sehingga produksi keasaman dapat tertunda 2-5 tahun.

Batuan PAF-Lag juga dapat digunakan sebagai bahan penyegelan sementara, tetapi tidak ditempatkan pada bagian slope terluar. Batuan sisa kelas 3 (PAF) dan kelas 4 (PAF-High Risk) adalah merupakan batuan sisa yang harus disegel atau dienkapsulasi pada bendungan tailing. Batuan ini merupakan material yang beresiko atau berpotensi untuk menghasilkan air asam tambang. Batuan sisa PAF dan PAF high Risk ini merupakan bahan yang memiliki nilai NAPP dan NAG pH yang rendah. Aktivitas penempatan batuan sisa pada bendungan tailing dapat dilihat pada Gambar 6.

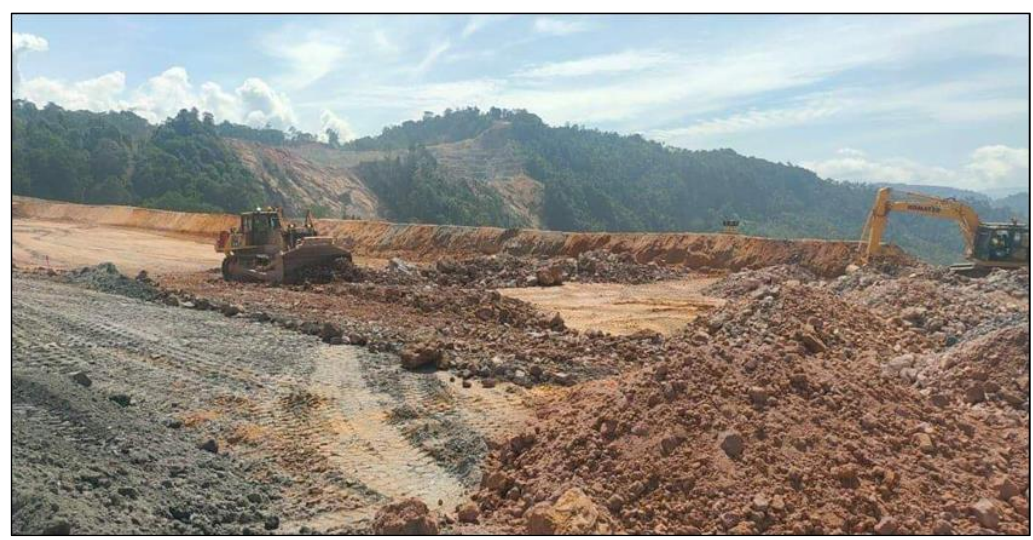

Gambar 6. Aktivitas penempatan batuan sisa pada bendungan tailing Sumber: Data lapangan tahun, 2020

Konsep teknis dengan material NAF yang secara progresif mengkapsulasi selama konstruksi bendungan tailing, pertarget peninggian tanggul bendungan tailing yaitu pada ketinggian 10 meter, dan batuan sisa dipadatkan setiap 1 meter tebal [14]. Konsep penempatan batuan sisa di bendungan tailing dan design enkapsulasi akhir bendungan tailing dapat dilihat pada Gambar 7 dan Gambar 8.

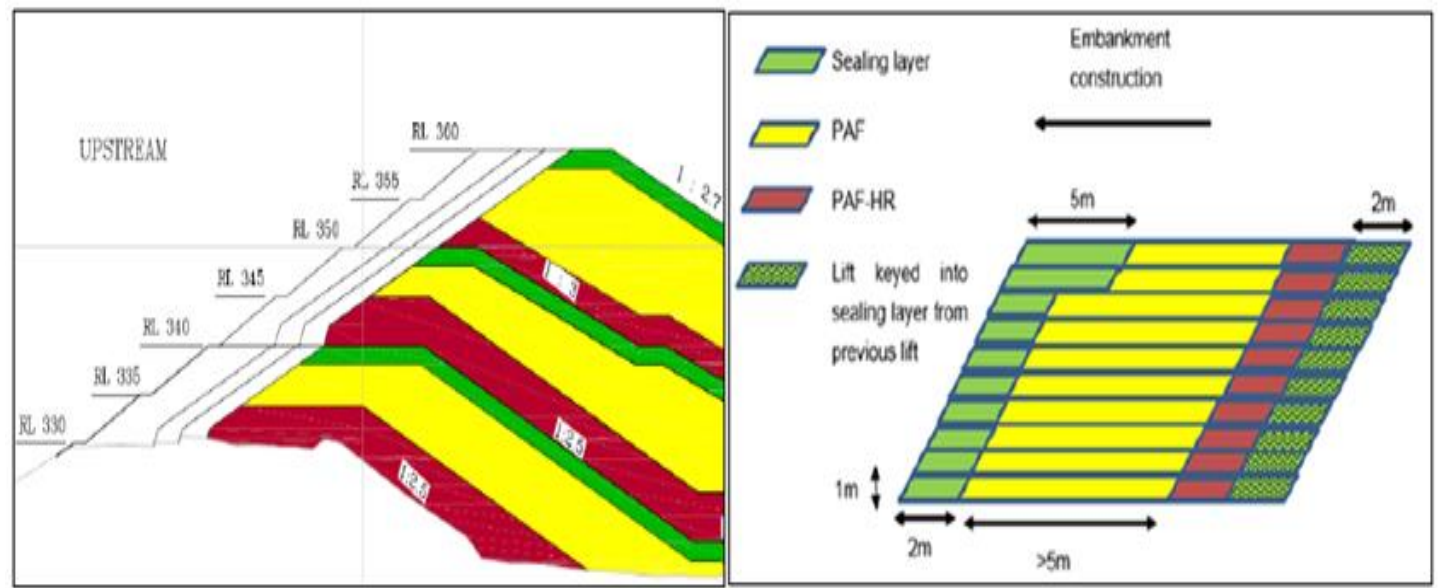

Gambar 7. Konsep penempatan batuan sisa dengan metode enkapsulasi pada bendungan tailing Sumber: Pedoman Teknis Pengelolaan Air Asam Tambang PTAR tahun 2015 


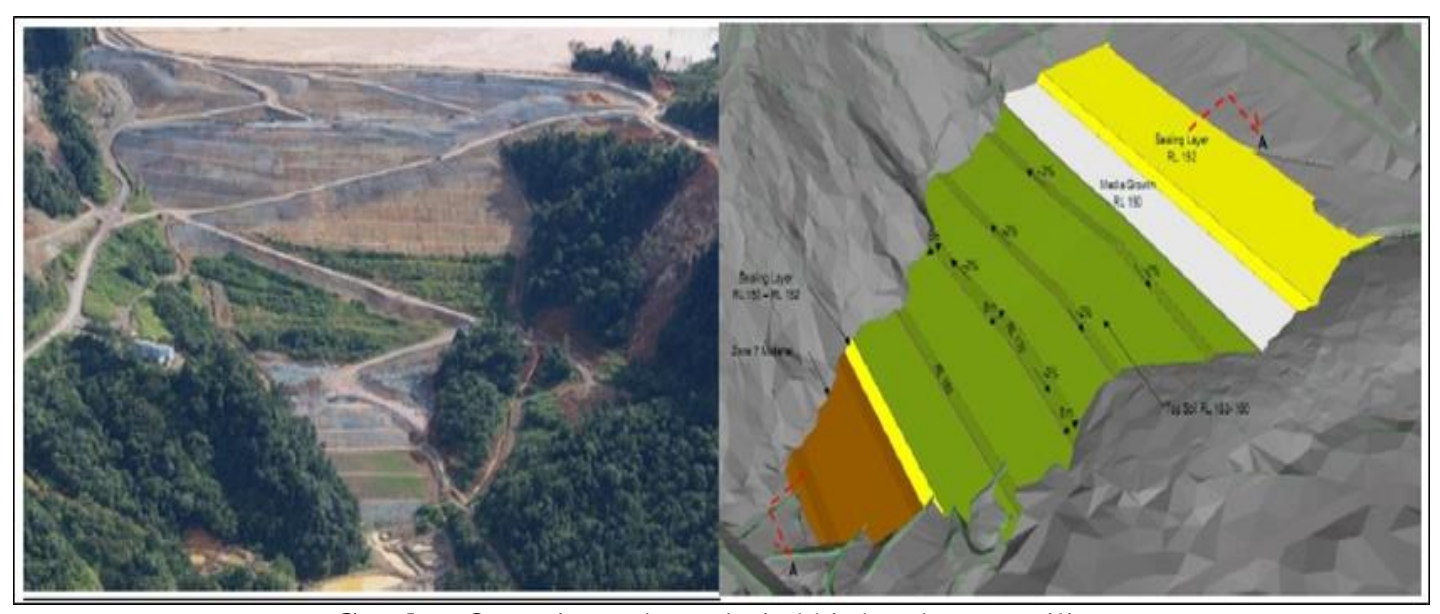

Gambar 8. Design enkapsulasi akhir bendungan tailing

Sumber: Data Lapangan Departemen TSF PTAR tahun 2019

Pemantauan kinerja atau performance bendungan tailing, setelah penempatan batuan sisa salah satunya dengan penempatan sensor pengukuran oksigen ingress di beberapa tempat di final bendungan tailing dan juga pengukuran $\mathrm{pH}$ air permukaan pada kaki bendungan tailing. Data yang dikumpulkan dari stasiun pemantauan, menunjukkan kalau lapisan penyegelan bekerja sesuai dengan konsep atau model. Data oksigen dalam lapisan penyegelan menunjukkan terjadinya penurunan oksigen hingga nol setelah penempatan material sebagai bagian dari peninggian tanggul. Konsentrasi oksigen dalam lapisan penyegelan dapat dilihat pada Gambar 9 [15].

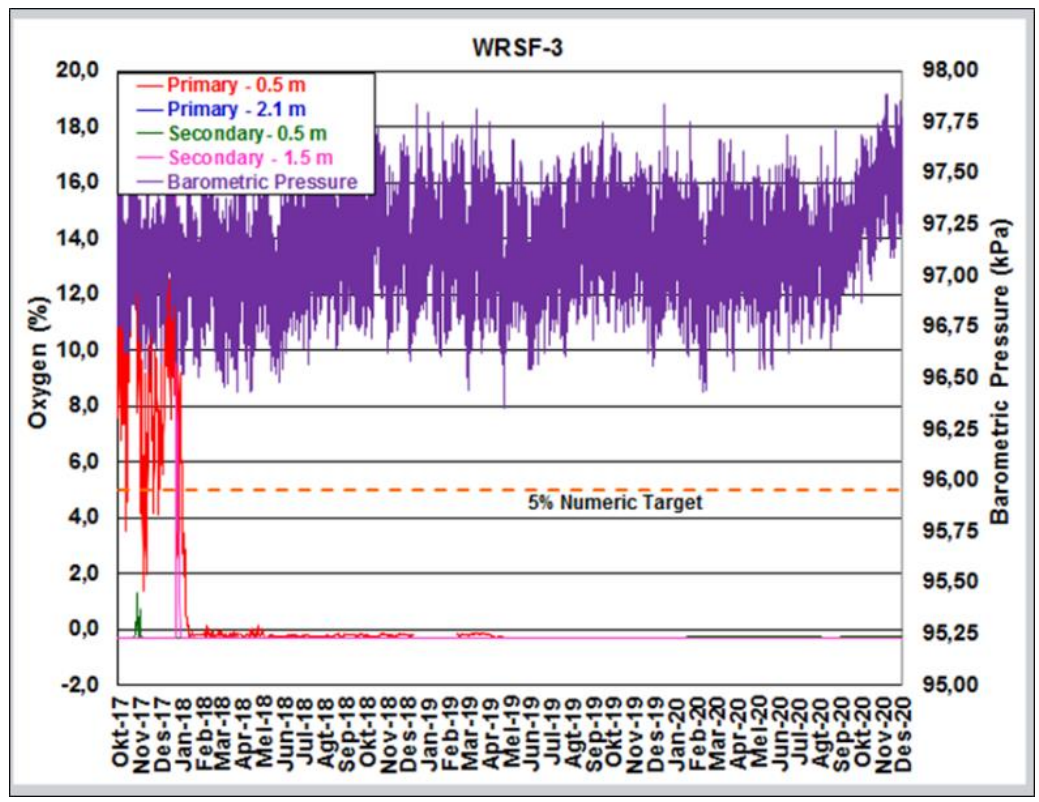

Gambar 9. Konsentrasi oksigen dalam lapisan penyegelan Sumber: Laporan Bulanan Departemen TSF PTAR 2020

Pengukuran curah hujan juga dilakukan di tambang emas Martabe, dengan memasang alat pengukur curah hujan (ombrometer) di beberapa titik. Pengukuran ini dilakukan, mengingat curah hujan merupakan salah satu faktor penting yang berperan dalam penyebaran air asam tambang. Penelitian ini memanfaatkan data curah hujan di area yang terdekat dengan bendungan tailing (RWT), dan dari total curah hujan bulanan, tambang emas Martabe memiliki curah hujan yang relatif tinggi. Total curah hujan bulanan di area sekitar bendungan tailing, dari Tahun 2014-2020 dapat dilihat pada Tabel 3 [16]. 
Tabel 3. Pengukuran curah hujan tahun 2014-2015 di area RWT

\begin{tabular}{|c|c|c|c|c|c|c|c|c|c|c|c|c|}
\hline \multirow{2}{*}{ Tahun } & \multicolumn{12}{|c|}{ Bulan } \\
\hline & Jan & Feb & Mar & Apr & May & Jun & Jul & Aug & Sep & Oct & Nov & Dec \\
\hline 2014 & & & & & & 193 & 271 & 11 & 348 & 250 & 556 & 491 \\
\hline 2015 & 515 & 98 & 301 & 385 & 244 & 205 & 205 & 434 & 361 & 258 & 516 & 437 \\
\hline 2016 & 291 & 121 & 502 & 389 & 656 & 276 & 390 & 316 & 252 & 518 & 542 & 531 \\
\hline 2017 & 526 & 200 & 394 & 330 & 426 & 153 & 146 & 282 & 365 & 345 & 774 & 345 \\
\hline 2018 & 264 & 355 & 600 & 481 & 328 & 171 & 388 & 310 & 318 & 694 & 792 & 423 \\
\hline 2019 & 394 & 239 & 354 & 340 & 298 & 189 & 203 & 452 & 209 & 422 & 253 & 549 \\
\hline 2020 & 356 & 223 & 301 & 499 & 358 & 245 & 452 & 216 & 477 & 361 & 298 & 490 \\
\hline
\end{tabular}

Sebagai konfirmasi kinerja bendungan tailing setelah dialiri air hujan yang cukup tinggi, dilakukan pengukuran $\mathrm{pH}$ air permukaan pada kaki bendungan tailing selama bulan Nopember-Desember. Hasil pengukuran menunjukkan kalau pH rata-rata air permukaan di kaki bendungan tailing, berada di 5,1-6,93. Data ini menunjukkan, enkapsulasi batuan sisa di bendungan tailing mampu menahan oksidasi sulfida yang terdapat pada batuan sisa PAF-High Risk, yang memiliki $\mathrm{pH}$ rata-rata $<3,5$ dan batuan sisa PAF yang sebagian besar pHnya diantara 3,5-6, sebelum dienkapsulasi dengan batuan class 1, 2 dan 5. Grafik pengukuran $\mathrm{pH}$ air permukaan dan $\mathrm{pH}$ batuan sisa PAF- High Risk di Pit Barani dan Ramba Joring dapat dilihat pada Gambar 10, 11 dan Gambar 12.

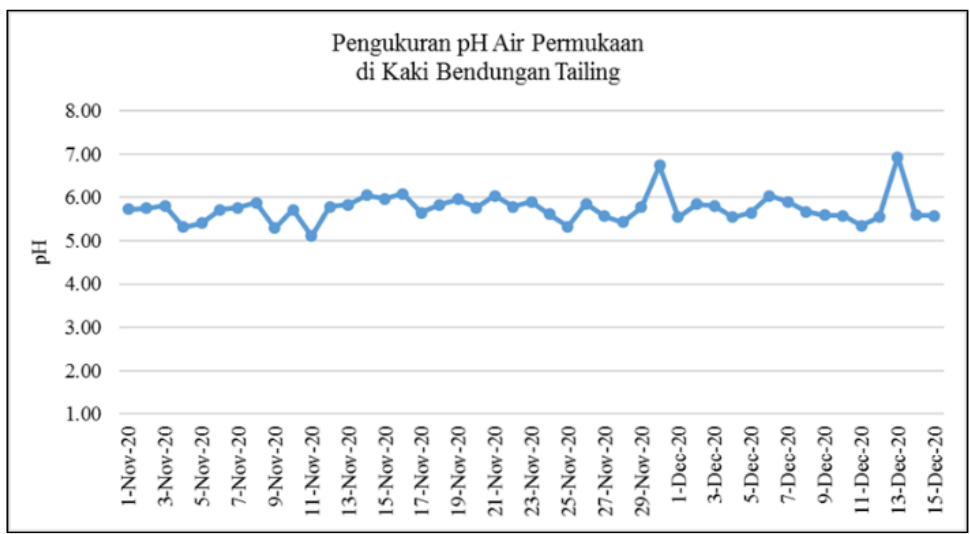

Gambar 10. Pengukuran $\mathrm{pH}$ air permukaan di kaki bendungan tailing Sumber: Analisis data tahun 2021

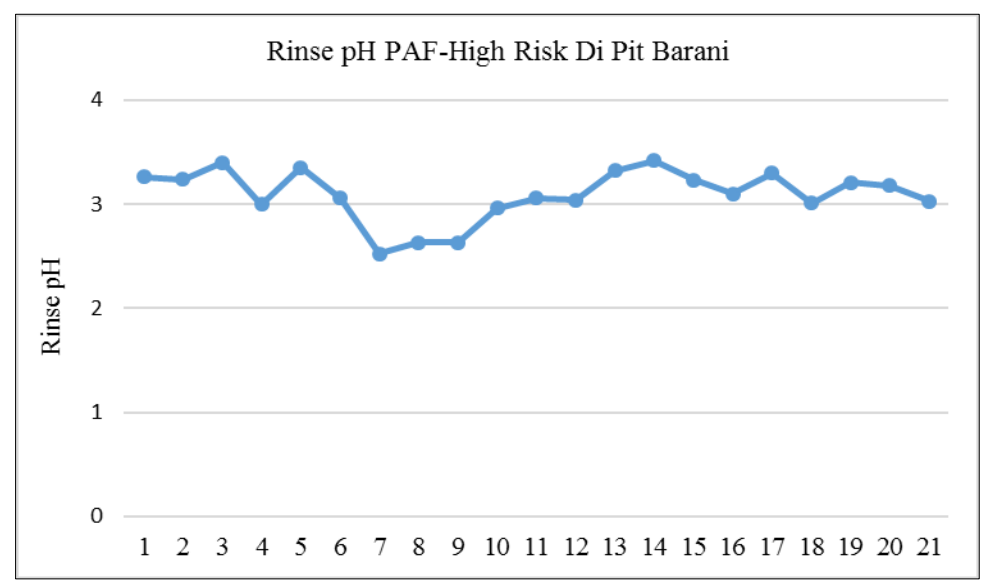

Gambar 11. Ph batuan sisa PAF high risk di Pit Barani Sumber: Analisis data tahun 2021 


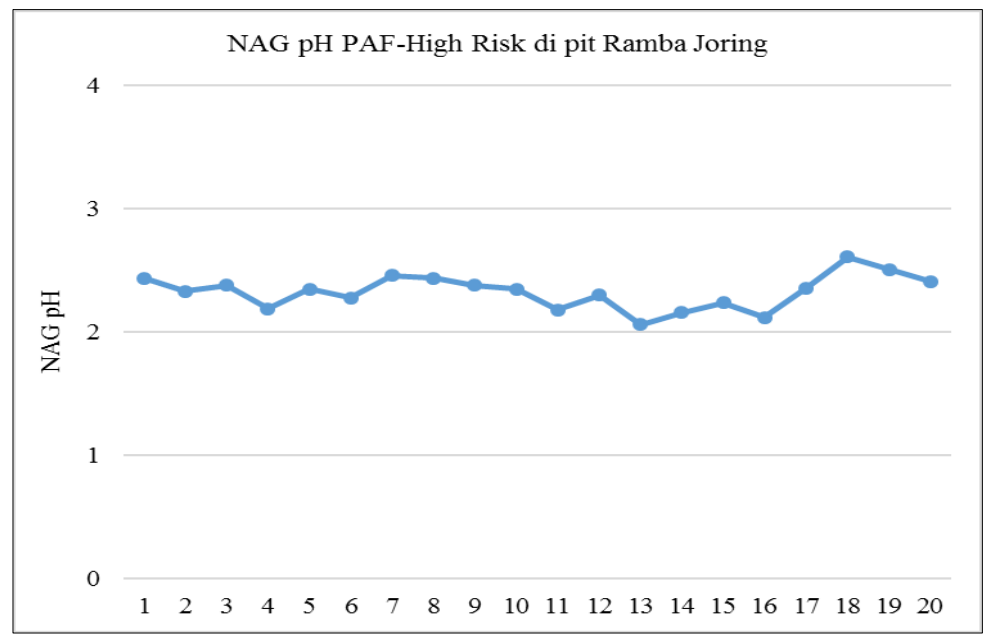

Gambar 12. Ph batuan sisa PAF High Risk di Pit Ramba Joring

Sumber: Analisis data tahun 2021

\section{Kesimpulan}

Permeabilitas batuan dan alterasi memiliki korelasi yang kuat dengan pembentukan batuan sisa PAF dan NAF di Pit Barani dan Ramba Joring. Batuan sisa dengan ukuran butiran seragam akan memiliki permeabilitas tinggi dan cenderung berpotensi membentuk batuan PAF seperti SSL, SST dan VANH, karena dapat meloloskan fluida sedangkan batuan sisa dengan ukuran butir beragam dan menyudut akan memiliki permeabilitas yang rendah sehingga lebih dominan membentuk bantuan NAF seperti BPM dan VBX. Alterasi pada batuan mengindikasikan temperatur dan keasaman, batuan PAF akan cenderung terbentuk pada alterasi AA dan SI, sedangkan batuan NAF mendominasi alterasi argillik.

Batuan sisa di Pit Barani memiliki resiko AMD yang lebih tinggi daripada batuan sisa di pit Ramba Joring, dilihat dari perbedaan komposisi mineral yang dimiliki oleh ke dua pit tersebut. Batuan sisa di Pit Barani ditempati oleh mineral sulfat pembentuk asam seperti geothite dan jarosite, sedangkan batuan sisa di Pit Ramba Joring didominasi oleh sulfat non asam yaitu alunite. Alunite berfungsi sebagai buffer atau penyangga oksidasi pirit, sehingga resiko AMD yang ditimbulkannya lebih rendah.

Pengelolaan air asam tambang dengan metode enkapsulasi di tambang emas Martabe, telah terbukti dapat menghambat terjadinya difusi udara ke dalam lapisan PAF (menghambat kontak mineral sulfida terhadap air dan udara), sehingga mampu mencegah pembentukan air asam tambang.

\section{Referensi}

[1] H. Lutfi, "Pengelolaan Lingkungan Areal Tambang Batubara (studi Kasus Pengelolaan Air Asam Tambang (Acid Mine Drainage) di PT. Bhumi Rantau Energi Kabupaten Tapin Kalimantan Selatan, “ADHUM, 7 (1), 2017.

[2] B. Joseph Kapuku, " A Review of Acid Mine Drainage in a Water-Scarce Country: Case of South Africa, "Environmental Management and Sustainable Development, 7 (1), 2018.

[3] M. Shinji, I. Hirotaka, S. Hideki, S. Takashi dan K. Ginting Jalu, "Characterization of Mine Waste and Acid Mine Drainage Prediction by Simple Testing Methods in Term of the Effects of SulfateSulfur and Carbonate Minerals, "Minerals, 8 (403), 2018.

[4] P. Baskara Widy Artyanto, P. Diyan, "Identifikasi Pembentukan Air Asam Tambang Batubara (PAF/NAF) Dengan Menggunakan Metode Uji NAPP (Net Acid Producing Potential), "STRING (Satuan Tulisan Riset dan Inovasi Teknologi), 4 (1), Agustus 2019.

[5] W. Bima Nugraha, P. Mohammad Irza Fandi, A. Jihan, "Pemodelan Persebaran Material PAF dan NAF pada PIT TIDAL, East Block, Wilayah Pertambangan Batubara Pit. Indominco Mandiri, di Wilayah Teluk Pandan, Kutai Timur, Kalimantan Timur, "Proseding Nasional Kebumian Ke-12, Teknik Geologi, Fakultas Teknik, Gadjah Mada, September 2019.

[6] P. Henny, P. Nova, Resiko Air Asam Tambang (AAT/AMD) Selama Tahap Konstruksi Fasilitas Penyimpanan Batuan Sisa Terpadu di Tambang Emas Martabe, PT Agincourtcourt Resources, 2017.

[7] P. Steven, A risk based-approach using process flow diagrams for operational waste rock classification - Case Study at Martabe Gold Mine, 2015. 
[8] P. Steven, H. Latipa, "Development of Leading Practice Waste Grade Control AMD Classification Methods Based on Deposit Spesific Mineralisation Characterisation and Modelling, "AMD Workshop, Australia, 2020.

[9] P. Steven, H. Latipa, "Sistem Pengelolaan Air asam Tambang Dari Material Waste dan Aplikasi Model Enkapsulasi Pada Bendungan TSF di Tambang Emas Martabe, "Prosiding TPT XXVIII Perhapi, Nusa Tenggara Barat, 2019.

[10] Kasmiani, W. Sri, B. Hasbi, "Analisis Potensi Air Asam Tambang Pada Batuan Pengapit Batubara di Salopuru Berdasarkan Karateristik Geokimia, "Geomine, 6 (3), Desember 2018.

[11] A. Rifqi, S. Lucas Donny, N. Nur Rochman, "Studi Alterasi Hidrotermal Endapan Timah Primer Prospek Burung mandi, Damar, Belitung, Bangka Balitung Berdasarkan Analisis Analytical Spectral Devices (ASD), X-Ray Diffraction (XRD) dan Petrografi, "Proceding Nasional Kebumian Ke-11, 2018.

[12] P. Steven, Martabe Mine Barani Pit: Geochemical Classification of Waste Rock. Barani Review, Report No. 863 (9), 2018.

[13] P. Steven, Martabe Mine Ramba Joring Pit: Geochemical Classification of Waste Rock. Ramba Joring Review, Report No. 863 (9), 2019.

[14] P. Steven, B. Mitchell, G. Ken, H. Janjan, P. Henny, O. Matthew dan C. Nugraha, "Progressive Management of AMD Risk During Construction of an Integrated Waste Rock Storage Landforms A Case Study at Martabe Gold Mine, Indonesia. Mine, "Water and Circular Economy Conference, Finlandia. 2017.

[15] PT.Agincourt Resources, Martabe Gold Mine Standard Operating Procedure for AMD Management at TSF, 2020

[16] PT.Agincourt Resources, Environmental Department Monthly Report, 2020 